\title{
Growth, Characterization and Morphology Study of Gel-Grown Lead-Cadmium-Mixed Levo-Tartrate Crystals
}

\author{
Harshkant Jethva ${ }^{1}$, Mihir Joshi ${ }^{2}$ \\ Corresponding Author: Harshkant Jethva \\ ${ }^{1,2}$ Saurashtra University, Department of Physics, Rajkot 360005, India
}

\begin{abstract}
Lead-cadmium mixed levo tartrate crystals for different compositions of lead and cadmium were grown by using single diffusion gel growth method in silica hydro gel medium. Long and dendrite type white crystals as well as star type crystals were obtained. The metallic composition in the crystals was estimated by EDAX. It was found that the metallic composition in the crystals vary as per the composition of supernatant solution, i.e., lead content was found more than cadmium content. The powder XRD suggested the monoclinic as well as orthorhombic nature. The grown crystals were characterized by FTIR spectroscopy and thermal studies. The FTIR spectra revealed the presence of water molecules, $\mathrm{O}-\mathrm{H}, \mathrm{C}-\mathrm{H}, \mathrm{C}-\mathrm{O}$ and $\mathrm{C}=\mathrm{O}$ functional groups. The thermo-grams suggested that the crystals were thermally unstable and decomposed into oxide through oxalate as well as carbonate stages.
\end{abstract}

Keywords: Lead-cadmium mixed levo-tartrate crystals, gel growth, FTIR, powder XRD, TG

\section{Introduction}

The gel growth technique is one of the simplest techniques for the growth of crystals under ambient condition, which are sparingly soluble in water and decompose at low temperature [1]. However, attempts have been made to grow crystals, which are soluble in water, by the gel growth technique [2]. Since, gel growth technique has several advantages over few disadvantages; it has attracted the attention of several researchers. In the literature, many tartrate compounds are reported which have been grown by the gel technique; for example, lead tartrate [3], cadmium tartrate [4]-[5], iron tartrate [6], cobalt tartrate [7]-[9], mixed iron-manganese tartrate [10] and ternary iron-manganese-cobalt tartrate [11] as well as ternary iron-manganese-nickel tartrate [12]. Lead tartrate finds application as an additive in gasoline to increase the performance of the engine [13], where as cadmium tartrate is well known for its piezoelectric application [14]. This prompted the present authors to grow cadmium and lead mixed levo tartrate crystals by varying the compositions and characterize them by EDAX, Powder XRD, FTIR and TG.

\section{Experimental}

Sodium metasilicate solution of density $1.05 \mathrm{gm} / \mathrm{cm}^{3}$ was used for preparation of gel. Solution of 1 molar levo tartaric acid was mixed with the solution of sodium metasilicate and the $\mathrm{pH}$ of the mixture was kept at 4.5. The mixture was poured in different test tubes of $25 \mathrm{~mm}$ diameter and $140 \mathrm{~mm}$ length to set into the gel. The supernatant solutions containing different proportions of $1 \mathrm{M}$ lead nitrate and $1 \mathrm{M}$ cadmium nitrate solutions were gently poured on the set gel without disturbing the gel surfaces. The composition of the supernatant was as under.

(I) $1 \mathrm{M}, 2 \mathrm{ml} \mathrm{Pb}\left(\mathrm{NO}_{3}\right)_{2}+1 \mathrm{M}, 8 \mathrm{ml} \mathrm{Cd}\left(\mathrm{NO}_{3}\right)_{2} \cdot 4 \mathrm{H}_{2} \mathrm{O}$

(II) $1 \mathrm{M}, 8 \mathrm{ml} \mathrm{Pb}\left(\mathrm{NO}_{3}\right)_{2}+1 \mathrm{M}, 2 \mathrm{ml} \mathrm{Cd}\left(\mathrm{NO}_{3}\right)_{2} \cdot 4 \mathrm{H}_{2} \mathrm{O}$
All the chemicals were AR grade and obtained from Ranbaxy chemicals. The following reaction is expected to occur.

$(1-\mathrm{X}) \mathrm{Pb}\left(\mathrm{NO}_{3}\right)_{2}+\mathrm{XCd}\left(\mathrm{NO}_{3}\right)_{2} \cdot 4 \mathrm{H}_{2} \mathrm{O}+\mathrm{H}_{2} \mathrm{C}_{4} \mathrm{H}_{4} \mathrm{O}_{6}+\mathrm{nH}_{2} \mathrm{O} \rightarrow$ $\mathrm{Cd}_{\mathrm{X}} \mathrm{Pb}_{(1-\mathrm{X})} \mathrm{C}_{4} \mathrm{H}_{4} \mathrm{O}_{6} \cdot \mathrm{nH}_{2} \mathrm{O}+4 \mathrm{HNO}_{3}+5 \mathrm{H}_{2} \mathrm{O}+1 / 2 \mathrm{O}_{2}$,

where $\mathrm{X}=0.8$ and 0.2 . Exact value of $\mathrm{X}$ is to be determined from EDAX analysis. The amount of $\mathrm{HNO}_{3}$ produced is very less in comparison to the nutrients being supplied to the growing crystals and hence no major limitation is imposed [1],[11],[12]-[15].

The growth was completed within twenty days. The nature of the grown crystals was dendrite for both the samples at the gel-liquid interface but the density of the dendrite type crystals and their lengths changed as per the composition of the supernatant solutions. At the bottom of the test tube of sample I, star type yellowish crystals were observed. Growth of crystals inside the test tubes is shown in figure 1(a-b) for the solution (I-II).

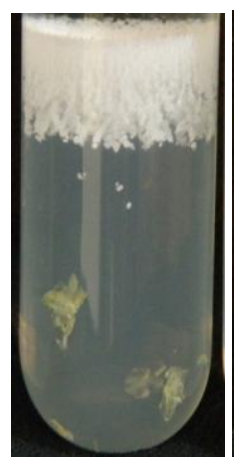

$1(\mathrm{a})$

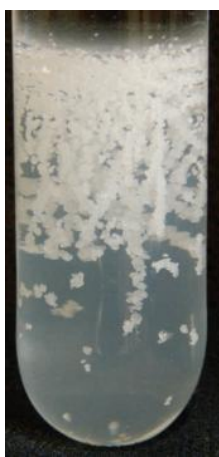

1(b)
Figure 1: Growth of crystals in gel

\section{Volume 4 Issue 12, December 2015}




\section{International Journal of Science and Research (IJSR) \\ ISSN (Online): 2319-7064}

Index Copernicus Value (2013): 6.14 | Impact Factor (2014): 5.611

Earlier, the present authors have grown and reported [15] the lead-cadmium mixed levo tartrate crystals by taking the composition of the supernatant solutions as:

$1 \mathrm{M}, 4 \mathrm{ml} \mathrm{Pb}\left(\mathrm{NO}_{3}\right)_{2}+1 \mathrm{M}, 6 \mathrm{ml} \mathrm{Cd}\left(\mathrm{NO}_{3}\right)_{2} \cdot 4 \mathrm{H}_{2} \mathrm{O}$ and $1 \mathrm{M}, 6$ $\mathrm{ml} \mathrm{Pb}\left(\mathrm{NO}_{3}\right)_{2}+1 \mathrm{M}, 4 \mathrm{ml} \mathrm{Cd}\left(\mathrm{NO}_{3}\right)_{2} \cdot 4 \mathrm{H}_{2} \mathrm{O}$

The crystals observed were white, long, dense and dendrite in nature.

In the present case, as the volume concentration of lead nitrate was decreased from $4 \mathrm{ml}$ to $2 \mathrm{ml}$ and cadmium nitrate was increased from $6 \mathrm{ml}$ to $8 \mathrm{ml}$, it was observed that the morphology of the crystals was changed considerably. The yellowish and irregular shaped crystals were observed at the bottom of the gel and dense, white and short dendrite crystals were observed at the gel-liquid interface. As the volume concentration of lead nitrate was increased from $6 \mathrm{ml}$ to $8 \mathrm{ml}$ and cadmium nitrate was decreased from $4 \mathrm{ml}$ to $2 \mathrm{ml}$, less dense, white and long dendrite crystals were observed at the gel-liquid interface but no crystals were observed at the bottom of the gel.

\section{Characterization Techniques}

The grown crystals were characterized by different techniques. The EDAX was carried out on Philips XL - 30 set up. The Powder XRD patterns were recorded on Philips X'pert MPD by using $\mathrm{Cu} \mathrm{K}_{\alpha}$ radiation and the data were analyzed by software powder-x. The FTIR spectra were recorded on Perkin Elmer Spectrum GX spectrophotometer in the range from $400-4000 \mathrm{~cm}^{-1}$ in $\mathrm{KBr}$ medium. The TG was conducted on Linseis (STA PT 1600) from room temperature to $700^{\circ} \mathrm{C}$ at a heating rate of $10^{\circ} \mathrm{C} / \mathrm{min}$ in atmosphere of air in standard $\mathrm{Al}_{2} \mathrm{O}_{3}$ crucible.

\section{Result and Discussion}

From figure $1(a-b)$ one observes that in the test tubes both dendrite type and star type crystals are grown. The composition of grown crystals was determined by EDAX and listed in the table 1 for the crystals grown near the interface of the gel and at the depth of about $3 \mathrm{~cm}$ from the gel-liquid interface.

From the table 1, it is observed that in the case of samples I and II, the percentage weight of $\mathrm{Pb}$ is high in the dendrite type crystals at the gel-liquid interface, while in the star type crystals at the bottom of the gel of sample I, the percentage weight of $\mathrm{Cd}$ is very high.

Table 1: EDAX result for $\mathrm{Pb} \mathrm{Cd}$ mixed levo tartrate crystals

\begin{tabular}{|c|c|c|c|c|c|c|}
\hline \multirow{2}{*}{$\begin{array}{c}\text { Sample } \\
\text { No. }\end{array}$} & \multirow{2}{*}{$\begin{array}{c}\text { Expected } \\
\text { atomic } \\
\text { weight (\%) }\end{array}$} & \multicolumn{4}{|c|}{$\begin{array}{c}\text { Observed atomic weight (\%) } \\
\text { (From EDAX) }\end{array}$} \\
\cline { 4 - 7 } & \multicolumn{2}{|c|}{$\begin{array}{c}\text { crystals near the } \\
\text { gel interface }\end{array}$} & \multicolumn{2}{c|}{$\begin{array}{c}\text { crystals below the } \\
\text { gel interface }\end{array}$} \\
\cline { 4 - 7 } & $\mathrm{Pb}$ & $\mathrm{Cd}$ & $\mathrm{Pb}$ & $\mathrm{Cd}$ & $\mathrm{Pb}$ & $\mathrm{Cd}$ \\
\hline I. & 20 & 80 & 65.17 & 34.83 & 1.81 & 98.19 \\
\hline II. & 80 & 20 & 98.58 & 1.42 & & \\
\hline
\end{tabular}

There is a clear compositional difference between dendrite type crystals at the gel-liquid interface for both the samples I and II and star type crystals at the bottom of gel column for the sample I. Mechanism of dendrite crystal growth was studied by Fujiwara and Nakajima [16]. Dendrite type growth morphology has been observed by several authors in the gel grown crystals, such as lead tartrate [17], cadmium tartrate [18], ammonium tartrate [19] and lanthanum tartrate [20]. In the present study to grow lead and cadmium mixed levo tartrate crystals, the supernatant ions of $\mathrm{Pb}^{+2}$ and $\mathrm{Cd}^{+2}$ slowly diffused into the gel medium where they react with tartrate anions already present. The crystal growth was started about two days after pouring the supernatant solution at the gel liquid interface in the form of a thin layer of very small crystalline particles. As the content of lead was increased in the supernatant solution, this layer became dense and thick with white crystals in dendrite form, which was due to fast growth rate in one direction and unstable growth front. However, it was observed that as the supernatant reactants percolated through the porous gel, the controlled reaction occurred at the depth of about $3 \mathrm{~cm}$ in the gel column, which was almost uniform in all direction and hence star type crystals were grown at the bottom of the test tubes. As noted earlier, both parent materials crystals, i.e. lead nitrate and cadmium nitrate crystals are in dendrite form and that nature is persistent in the mixed crystals of lead and cadmium levo tartrate grown at the gel-liquid interface.

It is found that as the volume of lead nitrate is increased in the supernatant solution, the wt $\%$ of lead entering the lattice is also increased but cadmium does not enter the lattice as per the volume of cadmium nitrate in the supernatant solution. The reason can be explained on the basis of hydrated radii. In the solution, $\mathrm{Pb}^{+2}$ and $\mathrm{Cd}^{+2}$ ions possess a primary hydration shell, which is the number of water molecules directly coordinated to both the metal ions. There is also overall solvation number, which is defined as the total number of water molecules associated when the solvent is water, on which both the ions exercise a substantial restraining influence. Then the successive layers of water molecules are termed as the secondary hydration layers. Hydration of an ion depends on the electrostatic attraction of water molecules to that ion. Attraction of water molecules around an ion depends on the density of charge of ion. The smaller ions having greater ionic potential attract more water molecules. The result is the inverse relationship between non-hydrated radius and hydrated radius. In this study, the non-hydrated radius of $\mathrm{Pb}^{+2}$ is $1.19 \AA$ and second ionization potential is $15.028 \mathrm{eV}$ while the same quantity for $\mathrm{Cd}^{+2}$ are $0.97 \AA$ and $16.908 \mathrm{eV}$, respectively. Therefore, the reverse nature is observed for hydrated radii of $\mathrm{Pb}^{+2}$ and $\mathrm{Cd}^{+2}$ than that for the non-hydrated ones [21],[22]. As the hydrated radii of $\mathrm{Pb}^{+2}$ being smaller than the hydrated radii of $\mathrm{Cd}^{+2}$, the $\mathrm{Pb}^{+2}$ ions enter into the reaction in higher concentration than $\mathrm{Cd}^{+2}$ ions, which is resulting higher concentration of $\mathrm{Pb}$ in grown crystals than $\mathrm{Cd}$. For the star type crystals below gel-liquid interface for supernatant solution I, the \%wt of $\mathrm{Cd}$ is more than that of $\mathrm{Pb}$. This can be explained on the basis of reactivity. The higher the ionization potential, the more difficult is to remove an electron and hence, less reactive the element. In this case, the ionization potential of $\mathrm{Cd}^{+2}$ ions is more than that of $\mathrm{Pb}^{+2}$ ions. Therefore, $\mathrm{Cd}^{+2}$ ions are less reactive and enter the gel deeper, which results into star type growth of crystals with higher content of $\mathrm{Cd}^{+2}$ ions. Also, the $\mathrm{Pb}^{+2}$ ions being more

\section{Volume 4 Issue 12, December 2015}




\section{International Journal of Science and Research (IJSR) \\ ISSN (Online): 2319-7064}

Index Copernicus Value (2013): 6.14 | Impact Factor (2014): 5.611

reactive and their higher concentration is available at the gelliquid interface, they are mainly responsible for dendritc crystal growth. But as one moves deeper in to the gel the concentration of $\mathrm{Pb}^{+2}$ ions in the gel column decreases as those are used up in the dendritic growth and hence in the star type crystals the concentration of $\mathrm{Pb}^{+2}$ ions is comparatively less than that of the dendritic crystals.

\subsection{Powder XRD Study}

The powder XRD pattern of the grown crystals at gel-liquid interface for the samples (I-II) and below gel-liquid interface for sample I are shown the figure 2. The unit cell parameters were computed by using computer software Powder-X and are given in table 2 .

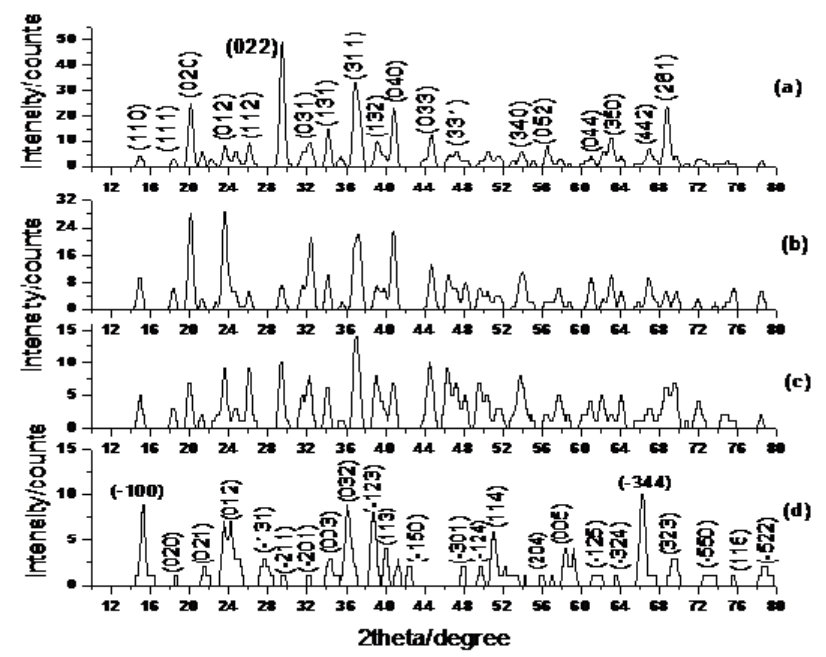

Figure 2: XRD patterns (a) pure lead tartrate (b) sample I (c) sample II for dendrite crystals at gel-liquid interface and (d)

sample I for star type crystals below gel-liquid interface

Table 2: Unit cell parameters and system for samples (I-II)

\begin{tabular}{|c|c|c|}
\hline Sample Name & Unit cell parameters & System \\
\hline $\begin{array}{l}\text { Sample I } \\
\text { at gel-liquid interface }\end{array}$ & $\begin{array}{l}\mathrm{a}=5.90 \AA, \mathrm{b}=8.816 \\
\AA \hat{\AA}, c=8.8500 \AA\end{array}$ & $\begin{array}{l}\text { Monoclinic } \\
\alpha=\gamma=90^{\circ}, \beta= \\
116.54^{\circ}\end{array}$ \\
\hline $\begin{array}{l}\text { Sample II } \\
\text { at gel-liquid interface }\end{array}$ & $\begin{array}{l}\mathrm{a}=7.9940 \AA, \mathrm{b}= \\
8.9017 \AA \hat{A}, \mathrm{c}=8.3500 \\
\AA\end{array}$ & $\begin{array}{l}\text { Orthorhombic } \\
\alpha=\beta=\gamma=90^{\circ}\end{array}$ \\
\hline $\begin{array}{l}\text { Sample I } \\
\text { below gel-liquid } \\
\text { interface }\end{array}$ & $\begin{array}{l}\mathrm{a}=7.413 \AA, \mathrm{b}= \\
12.3755 \AA \hat{,}, \mathrm{c}=7.731 \\
\AA\end{array}$ & $\begin{array}{l}\text { Monoclinic } \\
\alpha=\gamma=90^{\circ}, \beta= \\
116.57^{\circ}\end{array}$ \\
\hline
\end{tabular}

The orthorhombic unit cell parameters of lead tartrate crystals are: $\mathrm{a}=7.99482 \AA$, $\mathrm{b}=8.84525 \AA$, $\mathrm{c}=8.35318 \AA$ with space group $\mathrm{P} 22_{1} 2_{1}$ [23], while the monoclinic unit cell parameters of cadmium tartrate pentahydrate crystals are: $a=6.129 \AA$, b

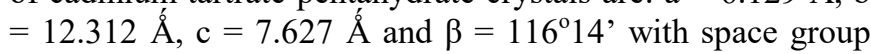
$\mathrm{P} 22_{1}$ [14]. It is observed that when cadmium is added into the lead levo tartrate, the intensity of all the peaks of mixed crystals of $\mathrm{Pb}$ and $\mathrm{Cd}$ is reduced. The scattering intensities for $\mathrm{X}$-rays are directly related to the number of electrons in the atom. Hence, light atoms scatter X-rays weakly, while heavy atoms scatter X-rays more effectively. Therefore, doping of light element i.e. $\mathrm{Cd}$, reduces the intensity of peaks. The percentage weight of cadmium in the structure of mixed cadmium-lead levo tartrate grown at gel-liquid interface of sample II is very less. Therefore, these crystals exhibit orthorhombic structure with the unit cell parameters close to the unit cell parameters of pure lead tartrate. As the percentage weight of cadmium is increased in the crystals grown at gel-liquid interface as well as grown below gelliquid interface of sample I, the crystal structure flips to the monoclinic [15] and unit cell parameters are altered and attempt to approach to the unit cell parameters of cadmium tartrate. It is also observed that the most intense peaks of pure lead tartrate $(020)$ at $21.12^{\circ},(022)$ at $29.44^{\circ},(031)$ at $32.25^{\circ}$, $(131)$ at $34.17^{\circ},(311)$ at $36.25^{\circ},(040)$ at $40.88^{\circ}$ and (261) at $68.79^{\circ}$ are shifted very little from their position in the crystals grown at gel-liquid interface of samples (I-II). This indicates that there is no strain produced in the structure of pure lead tartrate due to doping of cadmium because of low ionic radius of cadmium (0.92 $\AA$ ) compared to lead (1.19 $\AA$ ) [24]. The peaks of $\mathrm{Cd}$ are not separately identified in the mixed crystals of lead and cadmium levo tartrate grown at the gel-liquid interface of samples (I-II), indicating probably substitution of cadmium for lead in the grown crystals. The main peaks in powder XRD patterns of pure cadmium tartrate are (-100) at $16.23^{\circ},(-122)$ at $27.76^{\circ},(221)$ at $42.99^{\circ},(-303)$ at $48.05^{\circ},(-$ $310)$ at $50.32^{\circ},(-224)$ at $51.10^{\circ},(271)$ at $67.63^{\circ}$ and (342) at $75.29^{\circ}$ [25], which are found in the star type crystals at the bottom of the gel of sample I as $(-100)$ at $15.23^{\circ},(-131)$ at $27.62^{\circ},(-150)$ at $42.45^{\circ},(-301)$ at $47.90^{\circ},(-124)$ at $49.72^{\circ}$, $(114)$ at $51.08^{\circ},(-344)$ at $66.25^{\circ}$ and (116) at $75.57^{\circ}$. But the peaks of $\mathrm{Pb}$ are not separately identified in the star type crystals grown below gel-liquid interface of sample I, indicating very less amount of lead in the grown crystals.

From table 2, one can find that the crystals grown at gelliquid interface as well as below gel-liquid interface of sample I exhibit monoclinic structure, while the crystals grown at gel-liquid interface of sample II exhibit orthorhombic structure. This is indicates that the same nature of lead tartrate persists in the mixed crystals of lead and cadmium levo tartrate grown at the gel-liquid interface of sample II with low cadmium concentration but the nature changes from orthorhombic to monoclinic for the dendrite as well as star type crystals of sample I with higher cadmium concentration.

\subsection{FTIR Study}

The FTIR spectra are shown in figure 3.The plots (a) and (b) are for the dendrite crystals grown near the gel-liquid interface and the plot (c) is for the star type crystals grown below the gel-liquid interface for the sample I. The observed vibrational frequencies and their assignments are listed in the table 3. It can be observed from the spectra that the band between $3425 \mathrm{~cm}^{-1}$ to $3577 \mathrm{~cm}^{-1}$ is due to free O-H stretching vibrations representing water of crystallization or moisture on the surface. The absorption taking place around $1575 \mathrm{~cm}^{-1}$ and near $1380 \mathrm{~cm}^{-1}$ are due to $\mathrm{C}=\mathrm{O}$ stretching and $\mathrm{C}-\mathrm{H}$ stretching of alkane, respectively. The absorptions at 1076 $\mathrm{cm}^{-1}$ to $1080 \mathrm{~cm}^{-1}$ are due to $\mathrm{C}-\mathrm{O}$ stretching vibrations. The absorption occurring at nearly $2935 \mathrm{~cm}^{-1}$ and $2990 \mathrm{~cm}^{-1}$ are due to asymmetrical C-H stretching and absorption taking place around $2633 \mathrm{~cm}^{-1}$ and $2677 \mathrm{~cm}^{-1}$ are due to bonded $\mathrm{O}-\mathrm{H}$ stretching. The absorption occurring at $835 \mathrm{~cm}^{-1}$ for the crystals grown at gel-liquid interface for samples (I-II) is due to $\mathrm{C}-\mathrm{C}$ bending vibrations. The absorption bands found

\section{Volume 4 Issue 12, December 2015}




\section{International Journal of Science and Research (IJSR) \\ ISSN (Online): 2319-7064 \\ Index Copernicus Value (2013): 6.14 | Impact Factor (2014): 5.611}

between 690 and $530 \mathrm{~cm}^{-1}$ are due to metal-oxygen bonding vibration. It can be seen from the table 2 that the composition of cadmium and lead in the mixed levo tartrate crystals does not have significant effect on various absorptions in FTIR spectra.

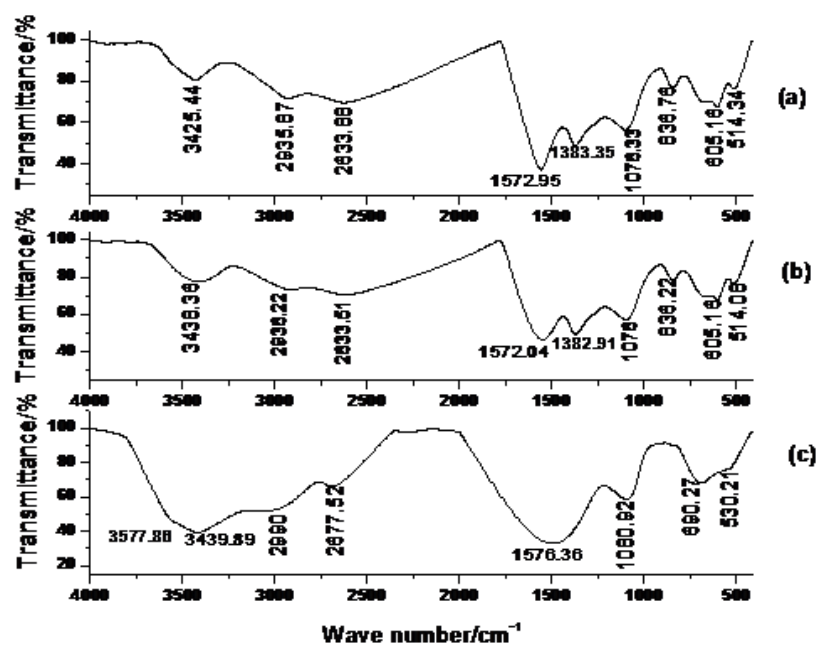

Figure 3: FTIR spectra (a) and (b) for the crystals of samples (I) and (II) grown at gel-liquid interface (c) for the crystals of sample (I) grown below gel-liquid interface

Table 3: FTIR spectral data for samples (I-II)

\begin{tabular}{|l|c|c|c|}
\hline \multicolumn{1}{|c|}{ Assignments } & $\begin{array}{c}\text { Wave number }\left(\mathrm{cm}^{-1}\right) \\
\text { Sample (I) at gel interface }\end{array}$ & $\begin{array}{c}\text { Wave number }\left(\mathrm{cm}^{-1}\right) \\
\text { Sample (II) at gel interface }\end{array}$ & $\begin{array}{c}\text { Wave number }\left(\mathrm{cm}^{-1}\right) \\
\text { Sample }(\text { I) below gel interface }\end{array}$ \\
\hline Free O-H Stretching & 3425.44 & 3438.36 & $3577.86,3439.89$ \\
\hline C-H Stretching (asymmetrical) & 2935.87 & 2936.22 & 2990.00 \\
\hline Bonded O-H Stretching & 2633.88 & 2633.51 & 2677.52 \\
\hline C=O Stretching & 1572.95 & 1572.04 & 1576.36 \\
\hline C-H Banding (Alkane) & 1383.35 & 1382.91 & \\
\hline C-O Stretching & 1076.33 & 1076.00 & 1080.92 \\
\hline C-C Bending & 836.76 & 836.22 & 690.27 \\
\hline Pb-O and Cd-O Stretching & $605.16,514.34$ & $605.16,514.08$ & 530.21 \\
\hline
\end{tabular}

However, comparing with the pure lead tartrate FTIR spectrum, one can find the differences in the absorption nature. In the pure cadmium levo tartrate crystal, the absorptions occur at $3364 \mathrm{~cm}^{-1}$ corresponding to $\mathrm{O}-\mathrm{H}$ stretching vibration [25] shifts to higher wave numbers in the present mixed crystals containing different proportions of lead and cadmium. Metal-oxygen vibrations for pure lead tartrate occur between $513.8 \mathrm{~cm}^{-1}$ to $605.4 \mathrm{~cm}^{-1}$ [3], while the same for cadmium tartrate occur between $513 \mathrm{~cm}^{-1}$ to $633 \mathrm{~cm}^{-}$ ${ }^{1}$ [25]. As shown in the table 3, the metal-oxygen vibrations for the mixed crystals of lead and cadmium occur between $514 \mathrm{~cm}^{-1}$ to $605 \mathrm{~cm}^{-1}$, indicating the same nature of metaloxygen vibrations persist in the mixed crystals of lead and cadmium grown at gel-liquid interface as well as below gelliquid interface of samples (I-II). There is no significant effect on other absorptions in FTIR spectra.

\subsection{Thermal Behavior}

There are reports available in literature on thermal studies on metal tartrate systems, for example, cadmium tartrate [4], cobalt tartrate [7], ternary iron-manganese-cobalt tartrate compound [11], ternary iron-manganese-nickel tartrate compound [12], lead-iron mixed levo tartrate crystals [26] and lead-cobalt mixed levo tartrate crystals [27].

Figure 4 shows the thermo-gram for the crystals grown near the gel-liquid interface and below the gel-liquid interface of samples (I-II).

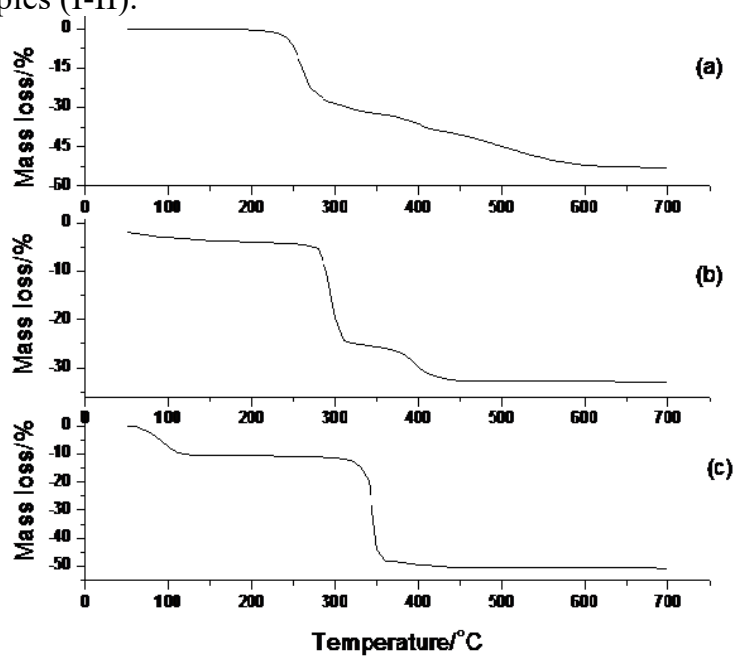

Figure 4: TG curves (a) and (b) for the crystals grown at gelliquid interface of samples (I-II) (c) for the crystals grown below gel-liquid interface of sample (I)

\section{Volume 4 Issue 12, December 2015}




\section{International Journal of Science and Research (IJSR) \\ ISSN (Online): 2319-7064}

Index Copernicus Value (2013): 6.14 | Impact Factor (2014): 5.611

For the crystals grown at gel-liquid interface of samples (I-II), the first stage of dehydration is completed up to $260{ }^{\circ} \mathrm{C}$ and $130{ }^{\circ} \mathrm{C}$, respectively, which results into formation of anhydrous lead-cadmium mixed tartrate. The second stage of decomposition of samples (I-II) is completed up to temperature $340{ }^{\circ} \mathrm{C}$ and $300{ }^{\circ} \mathrm{C}$, respectively, converting the anhydrous sample into oxalate from. The third and final stage of decomposition is completed up to temperature $570{ }^{\circ} \mathrm{C}$ for sample I, converting the crystals of sample I into oxide form. For the sample II, the third stage of decomposition is completed up to $370{ }^{\circ} \mathrm{C}$, converting the sample into carbonate form and during fourth and final stage of decomposition between 370 and $430{ }^{\circ} \mathrm{C}$, the sample is converted into oxide form.
In case of sample I thermo-gram the crystals grown below the gel-liquid interface, the first stage of dehydration occurs between $50-110^{\circ} \mathrm{C}$, resulting into formation of anhydrous lead-cadmium mixed tartrate. During the second stage between $110-350^{\circ} \mathrm{C}$, the anhydrous sample is converted into metastable carbonate form. The final stage of decomposition occurring between $350-430{ }^{\circ} \mathrm{C}$, converts the sample into oxide form.

Table 4 gives details of the thermal decomposition of the samples (I-II) for the crystals grown at gel-liquid interface and below gel-liquid interface with theoretically calculated and experimentally obtained mass loss values, respectively.

Table 4: Theoretical and experimental mass loss values of samples (I-II)

\begin{tabular}{|c|c|c|c|c|}
\hline \multirow[b]{2}{*}{ Sample name } & \multirow[b]{2}{*}{$T\left({ }^{\circ} \mathrm{C}\right)$} & \multirow[b]{2}{*}{ Reactions involved } & \multicolumn{2}{|c|}{ Mass loss in \% } \\
\hline & & & Calculated & From the graph \\
\hline \multirow{4}{*}{$\begin{array}{l}\text { Sample } \\
\text { I at gel-liquid interface }\end{array}$} & $50-200$ & No decomposition & 100 & 100 \\
\hline & $200-260$ & $\begin{array}{l}\mathrm{Pb}_{65.17} \mathrm{Cd}_{34.83} \mathrm{C}_{4} \mathrm{H}_{4} \mathrm{O}_{6} \cdot 3.4 \mathrm{H}_{2} \mathrm{O} \rightarrow \\
\mathrm{Pb}_{65.17} \mathrm{Cd}_{34.83} \mathrm{C}_{4} \mathrm{H}_{4} \mathrm{O}_{6}+3.4 \mathrm{H}_{2} \mathrm{O}\end{array}$ & 16 & 15.16 \\
\hline & $260-340$ & $\begin{array}{l}\mathrm{Pb}_{65.17} \mathrm{Cd}_{34.83} \mathrm{C}_{4} \mathrm{H}_{4} \mathrm{O}_{6} \rightarrow \mathrm{Pb}_{65.17} \mathrm{Cd}_{34.83} \mathrm{C}_{2} \mathrm{O}_{4}+ \\
2 \mathrm{CO}+2 \mathrm{H}_{2}\end{array}$ & 31.66 & 31.94 \\
\hline & $340-570$ & $\begin{array}{l}\mathrm{Pb}_{65.17} \mathrm{Cd}_{34.83} \mathrm{C}_{2} \mathrm{O}_{4} \rightarrow \mathrm{Pb}_{65.17} \mathrm{Cd}_{34.83} \mathrm{O}+2 \mathrm{CO}+ \\
1 / 2 \mathrm{O}_{2}\end{array}$ & 50.45 & 50.66 \\
\hline \multirow{5}{*}{$\begin{array}{l}\text { Sample } \\
\text { II at gel-liquid } \\
\text { interface }\end{array}$} & $0-50$ & No decomposition & 100 & 100 \\
\hline & $50-130$ & $\begin{array}{l}\mathrm{Pb}_{98.58} \mathrm{Cd}_{1.42} \mathrm{C}_{4} \mathrm{H}_{4} \mathrm{O}_{6} \cdot 0.5 \mathrm{H}_{2} \mathrm{O} \rightarrow \\
\mathrm{Pb}_{98.58} \mathrm{Cd}_{1.42} \mathrm{C}_{4} \mathrm{H}_{4} \mathrm{O}_{6}+0.5 \mathrm{H}_{2} \mathrm{O}\end{array}$ & 2.48 & 3.40 \\
\hline & $130-300$ & $\begin{array}{l}\mathrm{Pb}_{98.58} \mathrm{Cd}_{1.42} \mathrm{C}_{4} \mathrm{H}_{4} \mathrm{O}_{6} \rightarrow \mathrm{Pb}_{98.58} \mathrm{Cd}_{1.42} \mathrm{C}_{2} \mathrm{O}_{4}+ \\
2 \mathrm{CO}+2 \mathrm{H}_{2}\end{array}$ & 19.03 & 19.55 \\
\hline & $300-370$ & $\mathrm{~Pb}_{98.58} \mathrm{Cd}_{1.42} \mathrm{C}_{2} \mathrm{O}_{4} \rightarrow \mathrm{Pb}_{98.58} \mathrm{Cd}_{1.42} \mathrm{CO}_{3}+\mathrm{CO}$ & 26.48 & 26.35 \\
\hline & $370-430$ & $\mathrm{~Pb}_{98.58} \mathrm{Cd}_{1.42} \mathrm{CO}_{3} \rightarrow \mathrm{Pb}_{98.58} \mathrm{Cd}_{1.42} \mathrm{O}+\mathrm{CO}$ & 34.47 & 32.00 \\
\hline \multirow{4}{*}{$\begin{array}{l}\text { Sample } \\
\text { I below gel-liquid } \\
\text { interface }\end{array}$} & $0-50$ & No decomposition & 100 & 100 \\
\hline & $50-110$ & $\begin{array}{l}\mathrm{Pb}_{1.81} \mathrm{Cd}_{98.19} \mathrm{C}_{4} \mathrm{H}_{4} \mathrm{O}_{6} 1.6 \mathrm{H}_{2} \mathrm{O} \rightarrow \\
\mathrm{Pb}_{1.81} \mathrm{Cd}_{98.19} \mathrm{C}_{4} \mathrm{H}_{4} \mathrm{O}_{6}+1.6 \mathrm{H}_{2} \mathrm{O}\end{array}$ & 10.0 & 9.71 \\
\hline & $110-350$ & $\begin{array}{l}\mathrm{Pb}_{1.81} \mathrm{Cd}_{98.19} \mathrm{C}_{4} \mathrm{H}_{4} \mathrm{O}_{6} \rightarrow \mathrm{Pb}_{1.81} \mathrm{Cd}_{98.19} \mathrm{CO}_{3}+ \\
\mathrm{CH}_{4}+2 \mathrm{CO}+1 / 2 \mathrm{O}_{2}\end{array}$ & 40.27 & 42.00 \\
\hline & $350-430$ & $\mathrm{~Pb}_{1.81} \mathrm{Cd}_{98.19} \mathrm{CO}_{3} \rightarrow \mathrm{Pb}_{1.81} \mathrm{OCd}_{98.19} \mathrm{O}+\mathrm{CO}$ & 49.90 & 50.08 \\
\hline
\end{tabular}

The amount of water molecules attached with samples (I-II) for the crystals at gel-liquid interface and below the gel-liquid interface has been calculated. The proposed formula for the crystals of samples (I-II) is $\mathrm{Pb}_{0.2} \mathrm{Cd}_{0.8} \mathrm{C}_{4} \mathrm{H}_{4} \mathrm{O}_{6} \cdot \mathrm{nH}_{2} \mathrm{O}$ and $\mathrm{Pb}_{0.8} \mathrm{Cd}_{0.2} \mathrm{C}_{4} \mathrm{H}_{4} \mathrm{O}_{6} \cdot \mathrm{nH}_{2} \mathrm{O}$, respectively. The estimated formula from the EDAX and TGA for the crystals of sample (I-II) grown at gel liquid interface is $\mathrm{Pb}_{65.17} \mathrm{Cd}_{34.83} \mathrm{C}_{4} \mathrm{H}_{4} \mathrm{O}_{6} \cdot 3.4 \mathrm{H}_{2} \mathrm{O}$ and $\mathrm{Pb}_{98.58} \mathrm{Cd}_{1.42} \mathrm{C}_{4} \mathrm{H}_{4} \mathrm{O}_{6} \cdot 0.5 \mathrm{H}_{2} \mathrm{O}$, respectively and for the crystals of sample (I) below gel liquid interface is $\mathrm{Pb}_{1.81} \mathrm{Cd}_{98.19} \mathrm{C}_{4} \mathrm{H}_{4} \mathrm{O}_{6} \cdot 1.6 \mathrm{H}_{2} \mathrm{O}$.

\section{Conclusions}

The lead-cadmium levo tartrate crystals were grown by single diffusion gel technique in silica hydro gel medium. The dendrite type crystals were grown at gel-liquid interface and star type crystals were grown in the gel column below the gelliquid interface. It was found that the metallic content vary change as per the composition of supernatant solution containing lead nitrate and cadmium nitrate.
The EDAX analysis for gel-liquid interface grown crystals suggested that cadmium entered into the lattice in less amount with comparison to lead, which is due to the higher hydrated radius of $\mathrm{Cd}^{+2}$ ions compared to $\mathrm{Pb}^{+2}$ ions. The EDAX analysis for the crystals grown below gel-liquid interface suggested that cadmium entered into the lattice in very high amount with comparison to lead, which is due to less reactivity of $\mathrm{Cd}^{+2}$ ions. The FTIR spectra of the grown crystals indicated the presence of $\mathrm{O}-\mathrm{H}, \mathrm{C}-\mathrm{H}, \mathrm{C}-\mathrm{O}, \mathrm{C}-\mathrm{C}$ and $\mathrm{C}=\mathrm{O}$ functional groups with metal-oxygen vibrations. The powder XRD study suggested the monoclinic crystal structure of sample I and orthorhombic crystal structure of sample II, which indicated that the higher content of lead changed the crystal structure from monoclinic to orthorhombic. From the thermo-grams it was found that the crystals grown at gelliquid interface and below gel-liquid interface were thermally unstable. On heating they became anhydrous and decomposed into metal oxides through a single stage of oxalate for the crystals of sample I, grown at gel-liquid interface, through two stages of oxalate as well as carbonate for the crystals of 


\section{International Journal of Science and Research (IJSR) \\ ISSN (Online): 2319-7064}

Index Copernicus Value (2013): 6.14 | Impact Factor (2014): 5.611

sample II, grown at gel-liquid interface and through a single stage of carbonate for the crystals of sample I, grown below gel-liquid interface. The presence of water molecules was detected and calculated. The exact stoichiometric formulations for mixed crystals were suggested.

\section{Acknowledgments}

The authors are thankful to Prof. H. H. Joshi (HOD, Physics) for his keen interest and the author (HOJ) is thankful to the Principal and the Management of Maharaja Shree Mahendrasinhji Science College, Morbi for encouragements.

\section{References}

[1] H.K. Henisch, Crystal growth in gels, Pennsylvania University Press, University Park, 1970.

[2] K. Ambujam, Study on the growth and characterization of NLO active single crystals of KDP, $\gamma$-glycine, BGHC, CMTC and ZMTC, Ph. D Thesis, University of Madras, India, 2005.

[3] H.O. Jethva and M.V. Parsania, "Growth and characterization of lead tartrate crystals", Asian J. Chem. 22(8), 6317-6320, 2010.

[4] R.M. Dabhi and M.J. Joshi, "Thermal studies of gel grown cadmium tartrate crystals", Indian J. Phys., 77, 481-485, 2003.

[5] N.S. Patil, P.A. Chaudhari and D.S. Bhavsar, "Growth of cadmium tartrate crystals by gel technique", Arch. Appl. Sci. Res., 3(3): 272-278, 2011.

[6] S. Joseph, H.S. Joshi and M.J. Joshi, "Infrared spectroscopic and thermal studies of gel grown spherulitic crystals of iron tartrate", Cryst. Res. Technol., 32(2), 339-346, 1997

[7] S.J. Nandre, S.J. Shitole and R.R. Ahire, "FTIR, thermal and optical studies of gel grown cobalt tartrate crystals", J. Nano Electron. Phys. 5(4), 04050(1-5), 2013.

[8] V. Mathivanan, M. Haris, T. Prasanyaa and M. Amgalan, "Synthesis and characterization of gel grown cobalt tartrate crystals", Pramana J. Phys., 82(3), 537-548, 2014.

[9] S. Ariponnammal and T. Srinivasan, "Growth and spectroscopic characterization of cobalt tartrate crystals", Res. J. Recent Sci., 3, 63-66, 2014.

[10] S.J. Joshi, B.B. Parekh, K.D. Parikh, K.D. Vora and M.J. Joshi, "Growth and characterization of gel grown pure and mixed iron-manganese levo-tartrate crystals", Bull. Mater. Sci., 29(3), 307-312, 2006.

[11] S.J. Joshi, K.P. Tank, B.B. Parekh and M.J. Joshi, "Characterization of gel grown iron-manganese-cobalt ternary levo tartrate crystals", Cryst. Res. Technol., 45, 303-310, 2010.

[12] S.J. Joshi, K.P. Tank, B.B. Parekh and M.J. Joshi, "FTIR and thermal studies of iron-nickel-manganese ternary levo-tartrate crystals", J. Therm. Anal. Calorim., 10.1007/s10973-012-2624-8, 2012.

[13] N.J. Rahway, The Merck index of chemicals and drugs, 6th ed. Merck and Co.; 1952.

[14] J.S. Hopwood and A.W. Nicol, "Crystal data of cadmium tartrate pentahydrate", Crystallogr. J. Online., 16005767,1972
[15]H.O. Jethva, P.M. Vyas, K.P. Tank and M.J. Joshi, "FTIR and thermal studies of gel grown lead-cadmium mixed levo tartrate crystals", J. Therm. Anal. Calorim., 10.1007/s10973-014-3770-y, 2014.

[16]K. Fujiwara and K. Nakajima, Mechanism of dendritic crystal growth, Springer, 2009.

[17] M. Abdulkadhar and M.A. Ittyachen, "Development of lead tartrate crystals from its dendritic form", J. Cryst. Growth, 39, 365, 1977.

[18] R.M. Dabhi, B.B. Parekh and M.J. Joshi, "Dielectric studies of gel grown zinc tartrate crystals", Indian J. Phys., 79(5), 503, 2005

[19]A.D. Saraf, K.B. Saraf, P.A. Wani and S.V. Bhoraskar, "Dendritic growth of ammonium tartrate single crystals in Silica gel”, Cryst. Res. Technol., 21(4), 449, 1986.

[20]P.N. Kotru, N.K. Gupta and K.K. Raina, "Growth of lanthanum tartrate crystals in silica gel", J. Mater. Sci., 21, 90, 1986.

[21]Dove and Nix, "Ionic hydration in chemistry and biophysics", Geochimica et Cosmochimica Acta, 61, 3331, 1997.

[22] C.F. Albert, G. Wilkinson and P.L. Gaus, Basic Inorganic Chemistry, 3rd ed. John Wiley and Sons, pp 292, 1995.

[23]D.J.A. De Ridder, K. Goubitz, E.J. Sonneveld, W. Molleman and H. Schenk, "Lead tartrate from X-ray powder diffraction data:, Cryst. Stru. Comm., C58, m596-m598, 2002.

[24]B.D. Cullity, Elements of x-ray diffraction, AddisonWesley Publishing Company, pp 447, 1978.

[25] R.M. Dabhi, Ph. D. Thesis, Saurashtra University, Rajkot, India, 2002.

[26]H.O. Jethva and M.J. Joshi, "FTIR and thermal studies of gel grown lead-iron mixed levo-tartrate crystals", IJEIT, 4(1), 127-27, 2014.

[27] H.O. Jethva and M.J. Joshi, "FTIR and thermal studies of gel grown lead-cobalt mixed levo-tartrate crystals", IJIRSET, 3(9), 16517-16526, 2014.

\section{Author Profile}

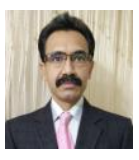

Harshkant Jethva received the M.Sc. degree in Physics from Saurashtra University, Rajkot, India in 1995 and joined as a lecturer in Physics at Maharaja Shree Mahendrasinhji Science College, Morbi, India in 1996. He obtained Ph.D. in 2015. At present, he is an associate professor in Physics in the same college.

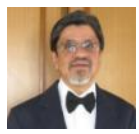

Mihir Joshi received the M. Sc. and Ph.D. degrees in Physics from Saurashtra University, Rajkot, India in 1982 and 1987, respectively. At present he is a Professor in Physics in the Department of Physics at the same university. 